PROFESI (Profesional Islam)

Media PublikasiPenelitian; 2017; Volume 15; No 1.

Website: ejournal@stikespku.ac.id

\title{
Hubungan Pendidikan dan Pekerjaan Ibu Terhadap Pemberian Mp-Asi Dini Pada Balita Usia 6-24 Bulan
}

\author{
Dewi Marfuah, Indah Kurniawati \\ S1 Gizi Stikes PKU Muhammadiyah Surakarta \\ Jl. Tulang Bawang Selatan no 26 Tegalsari RT 01 RW 32 Kadipiro Banjarsari Surakarta \\ dewi_marfuah@ymail.com, indah.kurniawati12@gmail.com
}

\section{Kata Kunci \\ Pendidikan, Pekerjaan,}

$M P-A S I$

\section{Keywords}

Education,

Employment,

Breastfeeding

Complementary

Feeding

\section{Abstrak}

Pemberian makanan pendamping ASI (MP-ASI) secara dini sangatlah berbahaya, apalagi jika disajikan tidak higienis. Bayi yang mendapat MP-ASI dini lebih berisiko terserang diare, sembelit, batuk pilek dan panas jika dibandingkan dengan bayi yang mendapat ASI eksklusif. Ada beberapa faktor yang dapat mempengaruhi ibu dalam pemberian MP-ASI dini pada bayi, seperti pengetahuan ibu, sosial budaya, pendidikan ibu, sikap ibu dan pekerjaan ibu. Tujuan penelitian ini untuk mengetahui hubungan pendidikan dan pekerjaan ibu terhadap pemberian MP-ASI Dini pada balita usia 6-24 bulan. Penelitian ini bersifat deskriptif analitik dengan rancangan cross sectional. Pengumpulan data dilakukan dengan kuesioner. Sampel dalam penelitian ini merupakan total populasi yaitu seluruh ibu yang mempunyai bayi 6-24 bulan di Posyandu Balita Bina Sejahtera I di Kelurahan Kadipiro Kecamatan Banjarsari Kota Surakarta berjumlah 37 orang. Analisis data dilakukan dengan uji Chi Square, dengan menggunakan program SPSS for windows versi 17,0, dengan $p$ value $=0,05$. Hasil penelitian ini menunjukkan terdapat hubungan antara pendidikan ibu dengan pemberian MP-ASI dini dengan p-value 0,007. Tidak terdapat hubungan antara status pekerjaan ibu dengan pemberian MP-ASI dini dengan p-value 0,053. Ada hubungan yang signifikan antara pendidikan ibu dengan pemberian MP-ASI dini pada balita usia 6-24 bulan.

\section{The Correlation Between Mother's Education and Job With The Early Feeding Practices In Toddler 6-24 Months)}

\begin{abstract}
Breastfeeding complementary feeding early is very dangerous, if it is presented not hygienic. Babies who received early breastfeeding complementary feeding were more at risk of diarrhea, constipation, cold and cough compared with the babies who get exclusive breastfeeding. There are several factors that can affect the mother in giving early breastfeeding at infants, such as mother's knowledge, socio-culture, mother education, mother's attitude and mother's job. The aim of the research is to determine the correlations of education and mother's jab on the provision of early MP-ASI in children aged 6-24 months. The research was analytic descriptive with cross sectional design. The data were collected by questionnaire. The sample in this study was the total population of all mothers who have babies 6-24 months in Posyandu Balita Bina Sejahtera I in Kelurahan Kadipiro District Banjarsari Surakarta City amounted to 37 people. Data analysis was done by Chi Square test, using SPSS for windows version 17.0, with $p$ value $=0,05$. The results of this study indicated there was correlation between maternal education with the provision of MP-ASI early with p-value 0.007. There was no correlation between maternal job status with early breastfeeding with p-value 0,053. There is a significant correlation between maternal education and early breastfeeding complementary feeding in children aged 6-24 months.
\end{abstract}




\section{PENDAHULUAN}

Balita merupakan kelompok umur yang rentan terhadap kelainan gizi karena pada saat ini mereka membutuhkan nutrisi yang optimal untuk pertumbuhan dan perkembangannya. Selain itu juga balita sangat pasif terhadap asupan makannya sehingga balita akan sangat bergantung pada orang tuanya (Aritonang, 2006; Santoso dan Anne, 2004). Pada balita yang kekurangan gizi akan terjadi kerusakan pada sistem kekebalan tubuh sehingga menyebabkan kerentanan terhadap suatu penyakit dan juga meningkatkan keparahan dan durasi penyakit yang mengakibatkan risiko kematian (Notatmojo S, 2011). Menurut World Health organization (WHO) gizi buruk mengakibatkan 54\% kematian bayi dan anak. Hasil sensus WHO menunjukkan bahwa $49 \%$ dari 10,4 juta kematian balita di negara berkembang berkaitan dengan gizi buruk. Tercatat sekitar $50 \%$ balita Asia, 30\% balita Afrika, 20\% Amerika Latin menderita gizi buruk (Depkes, 2010).

Angka gizi buruk sampai saat ini masih tinggi dan menjadi fokus perhatian dunia. Menurut data dari Food and Agriculture Organization (FAO) sekitar 870 juta orang dari 1,7 miliar penduduk dunia atau satu dari delapan orang penduduk dunia menderita gizi buruk. Sebagian besar (sebanyak 852 juta) diantaranya tinggal di negara berkembang. Indonesia merupakan salah satu negara berkembang dengan prevalensi gizi kurang pada tahun 2007 sebesar $18,4 \%$, kemudian mengalami penurunan pada tahun 2010 menjadi $17,9 \%$ dan mengalami peningkatan menjadi $19,6 \%$ pada tahun 2013 . Begitu juga prevalensi gizi buruk $5,4 \%$ pada tahun 2007 dan pada tahun 2010 turun menjadi 4,9\% kemudian mengalami peningkatan kembali pada tahun 2013 menjadi 5,7\% (Kemenkes, 2014).

ASI diberikan kepada bayi hingga berumur 24 bulan sebab ASI mempunyai keunggulan yang tak tergantikan oleh makanan apapun. ASI mengandung zat kekebalan yang dapat melindungi bayi dari berbagai penyakit dan mengandung semua zat gizi yang tepat dan lengkap dengan komposisi yang sesuai dengan kebutuhan bayi. Penelitian ilmiah menunjukkan bahwa anak-anak yang semasa bayi mendapatkan utamanya ASI eksklusif umumnya memiliki daya tahan tubuh yang kuat serta lebih cerdas sehingga dapat menghasilkan sumber daya manusia yang berkualitas (Prabantini, 2010).

Praktek pemberian makan yang baik dan tepat sangat penting untuk kelangsungan hidup, pertumbuhan dan perkembangan, serta kesehatan dan gizi bagi bayi. Pada umur enam bulan bayi sudah mulai diberikan Makanan Pendamping ASI (MP-ASI). Sebagian besar pemberian MPASI belum sesuai dengan umur bayi dan anak seperti pemberian MP-ASI dini dan terlambat memberikan MP-ASI yang keduanya sama-sama menimbulkan resiko atau efek negatif bagi bayi (Kemenkes, 2011).

Banyak orang tua menganggap bahwa kebutuhan makanan bayi tidak tercukupi jika hanya dengan memberikan ASI sehingga pemberian MP-ASI berupa susu formula dan makanan lainnya pada kalangan orang tua sudah biasa namun tidak memperhatikan beberapa resiko apabila ibu memberikan makanan Pendamping Air Susu Ibu (MP- ASI) terlalu dini pada bayi, seperti MP-ASI akan menggantikan ASI sehingga dapat menimbulkan efek negatif seperti sulit memenuhi kebutuhan bayi, dapat menimbulkan resiko diare karena MP-ASI tidak sebersih dan tidak mudah dicerna seperti ASI, kurang mengonsumsi zat anti. infeksi pada ASI sehingga bayi rentang terkena penyakit, dan masih banyak efek negatif yang ditimbulkan dari pemberian MP- ASI dini pada bayi Kemenkes, 2011).

Ada beberapa faktor yang dapat mempengaruhi ibu dalam pemberian MP-ASI dini pada bayi, seperti faktor dari ibu sendiri atau faktor dari luar. Faktor dari ibu yaitu pengetahuan ibu, sosial budaya, pendidikan, sikap ibu dan ibu yang bekerja diluar rumah sedangkan faktor dari luar seperti promosi susu formula, promosi kesehatan, fasilitas kesehatan dan sebagainya (Asmarudin Pakhri et al, 2015).

Berdasarkan hasil Riskesdas 2013, pemberian Makanan Pendamping Air Susu Ibu (MP-ASI) dini di Indonesia sudah tergolong tinggi karena pada umur bayi masih 0 bulan sudah diberikan makanan atau minuman selain ASI saja selama 24 jam terakhir sebanyak 47,3 $\%$, dan pada umur dibawah 6 bulan rata-rata pemberian MP-ASI dini sebanyak 66, $4 \%$. Ini berarti lebih dari setengah bayi di Indonesia sudah diberikan MP-ASI terlalu dini (Kemenkes, 2014). 
PROFESI (Profesional Islam)

Media PublikasiPenelitian; 2017; Volume 15; No 1.

Website: ejournal@stikespku.ac.id

\section{METODE}

Penelitian ini merupakan penelitian berbentuk survey dengan pendekatan deskriptif dan desain penelitian ini adalah cross sextional. Penelitian ini dilaksanakan pada bulan Mei s.d. Juni 2017. Tempat penelitian ini adalah di Posyandu Balita Bina Sejahtera I Kelurahan Kadipiro Kecamatan Banjarsari Kota Surakarta. Sampel adalah ibu yang memiliki anak usia 6 24 bulan yang ada di Posyandu Balita Bina Sejahtera I Kelurahan Kadipiro Kecamatan Banjarsari Kota Surakarta sebanyak 37 ibu balita. Pengambilan sampel dengan metode purposive sampling, dengan kriteria: ibu yang memiliki anak usia 6 - 24 bulan, anak dan ibu dalam kondisi sehat, dan bersedia menjadi sampel.

Variabel independen dalam penelitian ini adalah pendidikan ibu dan status pekerjaan ibu, sedangkan variabel dependen dalam penelitian ini adalah pemberian MP ASI Dini. Pekerjaan ibu diperoleh dari identitas responden, dikategorikan menjadi dua yaitu bekerja di dalam rumah dan bekerja di luar rumah sedangkan pendidikan ibu merupakan pendidikan terakhir ibu yang dibedakan mnjadi SD, SMP, SMA, Perguruan Tinggi. Pemberian MP ASI Dini adalah waktu pertama ibu memberikan MP ASI (dalam usia bulan bayi) dikategorikan menjadi dua: pemberian MP ASI dini jika pertama diberikan usia bayi < 6 bulan, tidak pemberian MP ASI dini jika pertama diberikan usia bayi $\geq 6$ bulan.

Instrumen penelitian yang digunakan adalah babyscale, babyboard, timbangan injak, microtoice, lembar kuesioner dan alat tulis. Lembar kuesioner untuk mendapatkan data tentang pendidikan, pengetahuan, pekerjaan ibu dan tentang MP- ASI Dini.

Setelah data terkumpul peneliti melakukan pengolahan data antara lain editing, coding, tabulasi dan narasi. Analisis data dilakukan dengan uji Chi Kuadrat, dengan menggunakan bantuan program SPSS for windows versi 17,0, dengan $\mathrm{p}$ value $=0,05$.

\section{HASIL DAN PEMBAHASAN \\ 3.1 Hasil}

Berdasarkan hasil penelitian yang dilakukan didapatkan karakteristik sampel yang terdiri dari jenis kelamin, usia ibu, pendidikan terakhir ibu, pekerjaan ibu dan status pemberian MP- ASI Dini. Pada Tabel 1 didapatkan bayi dan balita berjenis kelamin laki-laki sebanyak 18 anak $(48,6 \%)$ dan perempuan 19 anak $(51,4 \%)$.

Tabel 1. Distribusi Bayi dan Balita Berdasarkan Jenis kelamin

\begin{tabular}{lcc}
\hline \multirow{2}{*}{ Jenis Kelamin } & \multicolumn{2}{c}{ Jumlah } \\
\cline { 2 - 3 } & Frekuensi & $\%$ \\
\hline Laki - laki & 18 & 48,6 \\
Perempuan & 19 & 51,4 \\
Total & 37 & 100,0 \\
\hline
\end{tabular}

Tabel 2 menunjukkan distribusi sampel berdasarkan kelompok umur responden, didapatkan hasil bahwa kelompok umur responden yang paling banyak pada kelompok umur 16 - 25 tahun sebanyak 16 orang $(43,2 \%)$.

Tabel 2. Distribusi Responden Berdasarkan Umur

\begin{tabular}{lcc}
\hline \multirow{2}{*}{ Kelompok Umur } & \multicolumn{2}{c}{ Jumlah } \\
\cline { 2 - 3 } & Frekuensi & $\%$ \\
\hline $16-25$ tahun & 16 & 43,2 \\
$26-35$ tahun & 13 & 35,2 \\
$>35$ tahun & 8 & 21,6 \\
Total & 37 & 100,0 \\
\hline
\end{tabular}

Tabel 3 dibawah ini merupakan tabel distribusi pendidikan responden, menunjukkan hasil mayoritas pendidikan responden atau ibu balita adalah SMA sebanyak 17 orang (46\%). Namun, masih ada sampel dengan pendidikan terakhir SD sebanyak 6 orang $(16,2 \%)$.

Tabel 3. Distribusi Pendidikan Responden

\begin{tabular}{lcc}
\hline \multirow{2}{*}{ Pendidikan } & \multicolumn{2}{c}{ Jumlah } \\
\cline { 2 - 3 } & Frekuensi & $\%$ \\
\hline SD & 6 & 16,2 \\
SMP & 9 & 24,3 \\
SMA & 17 & 46,0 \\
Perguruan Tinggi & 5 & 13,5 \\
Total & 37 & 100,0 \\
\hline
\end{tabular}

Tabel 4 menunjukkan distribusi pekerjaan sampel paling banyak bekerja di dalam rumah yaitu sebanyak 23 orang $(62,2 \%)$. 
PROFESI (Profesional Islam)

Media Publikasi Penelitian; 2017; Volume 15; No 1.

Website: ejournal.stikespku.ac.id

Tabel 4. Distribusi Pekerjaan Responden

\begin{tabular}{lcc}
\hline \multirow{2}{*}{ Pekerjaan } & \multicolumn{2}{c}{ Jumlah } \\
\cline { 2 - 3 } & Frekuensi & $\%$ \\
\hline Bekerja di dalam rumah & 23 & 62,2 \\
Bekerja di luar rumah & 14 & 37,8 \\
Total & 37 & 100,0 \\
\hline
\end{tabular}

Tabel 5 menunjukkan distribusi pemberian MP-ASI Dini. Ibu yang memberikan MP-ASI secara dini sebanyak 24 orang $(64,9 \%)$
Tabel 5. Distribusi Pemberian MP - ASI Dini

\begin{tabular}{lcc}
\hline \multirow{2}{*}{$\begin{array}{c}\text { Pemberian MP- } \\
\text { ASI }\end{array}$} & \multicolumn{2}{c}{ Jumlah } \\
\cline { 2 - 3 } & Frekuensi & $\%$ \\
\hline$<6$ bulan & 24 & 64,9 \\
$\geq 6$ bulan & 13 & 35,1 \\
Total & 37 & 100,0 \\
\hline
\end{tabular}

Pada tabel 6 menunjukkan distribusi pendidikan ibu terhadap pemberian MP-ASI Dini. Hasilnya menunjukkan bahwa ada hubungan antara pendidikan ibu terhadap pemberian MP-ASI Dini $(\mathrm{p}=0,007)$.

Tabel 6. Distribusi Pendidikan Ibu Terhadap Pemberian MP-ASI Dini.

\begin{tabular}{|c|c|c|c|c|c|}
\hline \multirow{2}{*}{ Pendidikan } & \multicolumn{2}{|c|}{ Pemberian MP-ASI Dini } & \multirow{2}{*}{ Total } & \multirow{2}{*}{$x^{2}$} & \multirow[b]{2}{*}{$\mathrm{p}$} \\
\hline & $\mathrm{Ya}$ & Tidak & & & \\
\hline Tinggi & $8(61,5 \%)$ & $20(87 \%)$ & $28(75,7 \%)$ & 7,645 & 0,007 \\
\hline Rendah & $5(38,5 \%)$ & $3(13 \%)$ & $9(24,3 \%)$ & & \\
\hline Total & $14(100 \%)$ & $23(100 \%)$ & $37(100 \%)$ & & \\
\hline
\end{tabular}

Pada tabel 7 menunjukkan distribusi pekerjaan ibu terhadap MP-ASI Dini. Hasilnya menunjukkan bahwa tidak ada hubungan antara

pekerjaan ibu terhadap pemberian MP-ASI Dini $(\mathrm{p}=0,053)$.

Tabel 7. Distribusi Status Pekerjaan Ibu Terhadap Pemberian MP-ASI Dini.

\begin{tabular}{clcccc}
\hline \multirow{2}{*}{ Pekerjaan } & \multicolumn{2}{c}{ Pemberian MP-ASI Dini } & \multirow{2}{*}{ Total } & \multirow{2}{*}{$\boldsymbol{X}^{2}$} & $\mathrm{p}$ \\
\cline { 2 - 3 } & \multicolumn{1}{c}{ Ya } & Tidak & & \\
\hline Bekerja di dalam rumah & $7(36,8 \%)$ & $2(16,7 \%)$ & $9(29 \%)$ & 3,673 & 0,053 \\
Bekerja di luar rumah & $12(63,2 \%)$ & $10(83,3 \%)$ & $22(71 \%)$ & & \\
\multicolumn{1}{c}{ Total } & $19(100 \%)$ & $12(100 \%)$ & $31(100 \%)$ & & \\
\hline
\end{tabular}

\subsection{Pembahasan}

Makanan yang terbaik untuk bayi usia 0-6 bulan adalah Air Susu Ibu (ASI). ASI merupakan sumber energi terbaik dan paling ideal dengan komposisi yang seimbang sesuai dengan kebutuhan bayi pada masa pertumbuhan. Pemberian ASI diberikan sampai bayi berusia 6 bulan, setelah 6 bulan pemberian ASI saja tidak cukup untuk memenuhi seluruh kebutuhan makanan bayi, ASI hanya akan memenuhi sekitar 60-70\% kebutuhan bayi, sedangkan 30-40\% harus dipenuhi dari makanan pendamping atau makanan tambahan. ASI masih tetap diberikan hingga bayi berusia 2 tahun (UKK Nutrisi dan Penyakit Metabolik IDAI, 2015).

Makanan Pendamping ASI (MP-ASI) adalah makanan yang diberikan saat bayi mulai berumur 6 bulan. MP-ASI bukan merupakan makanan pengganti, MP- ASI hanya membantu melengkapi kebutuhan bayi saat umur mulai memasuki 6 bulan setelah pemberian ASI eksklusif (Gibson, 2008).

Banyak orang tua menganggap bahwa kebutuhan makanan bayi tidak tercukupi jika hanya dengan memberikan ASI sehingga pemberian MP-ASI berupa susu formula dan makanan lainnya pada kalangan orang tua sudah biasa namun tidak memperhatikan beberapa resiko apabila ibu memberikan MP-ASI terlalu dini pada bayi, seperti MP-ASI akan menggantikan ASI sehingga dapat menimbulkan efek negatif seperti sulit memenuhi kebutuhan bayi, dapat menimbulkan risiko diare karena MP-ASI tidak sebersih dan tidak mudah dicerna seperti 
ASI, kurang mengonsumsi zat anti infeksi pada ASI sehingga bayi rentang terkena penyakit, dan masih banyak efek negatif yang ditimbulkan dari pemberian MP- ASI dini pada bayi (Kemenkes, 2011).

Ada berbagai macam alasan yang dikemukakan ibu untuk memberikan MP-ASI dini, misalnya karena ibu bekerja sehingga tidak sempat memberikan ASI saja kepada bayi dan mengambil jalan lain seperti memberikan MPASI terlalu dini pada bayinya. Selain itu ada faktor lainnya seperti pengetahuan, pekerjaan, dan pendidikan ibu (Syerlia et al, 2014).

\subsubsection{Hubungan Pendidikan Ibu Terhadap Pemberian MP-ASI Dini.}

Pendidikan membantu seseorang untuk menerima informasi tentang pertumbuhan dan perkembangan bayi, misalnya memberikan Makanan Pendamping ASI (MP- ASI) di usia bayi memasuki 6 bulan. Proses pencarian dan penerimaan informasi akan lebih cepat jika ibu berpendidikan tinggi (Asmarudin Pakhri et al, 2015).

Uji statistik dengan menggunakan komputer dengan program SPSS dengan uji Chi-square menunjukkan bahwa tidak ada hubungan yang bermakna antara faktor pendidikan ibu dengan pemberian MP-ASI dini pada usia bayi 6-24 bulan, dengan nilai $p=1.00>\alpha 0,05$.

Hasil analisa statistik tersebut menunjukkan bahwa faktor pendidikan tidak mempengaruhi seorang ibu dalam pemberian MP-ASI terlalu dini pada bayinya. Berdasarkan hasil wawancara, banyak ibu yang berpendidikan tinggi, namun mereka belum tahu dan mengerti tentang MPASI. Ada pula ibu yang berpendidikan tinggi dan memiliki pengetahuan yang baik tentang MPASI tetapi tidak menerapkan pemberian MP- ASI tepat pada waktunya hal ini disebabkan karena ketidaktahuan dan kurangnya informasi tentang MP-ASI itu sendiri (Asmarudin Pakhri et al, 2015).

Ibu dengan pendidikan rendah belum tentu tidak memberikan MP-ASI tepat pada waktu kepada bayinya karena meskipun berpendidikan rendah, kalau ibu tersebut rajin mendengarkan atau melihat informasi mengenai MP-ASI, tidak mustahil pengetahuan mereka akan lebih baik (Asmarudin Pakhri et al, 2015).

Menurut Notoatmodjo (2010), pendidikan adalah kegiatan atau proses belajar yang terjadi dimana saja, kapan saja, dan oleh siapa saja. Seseorang dapat dikatakan belajar apa bila didalam dirinya terjdi perubahan dari tidak tahu menjadi tahu, dari tidak mengerjakan menjadi dapat mengerjakan sesuatu. Berdasarkan pengertian tersebut dapat diartikan bahwa pendidikan tidak hanya didapatkan di bangku sekolah sebagai pendidikan formal akan tetapi dapat diperoleh kapan dan dimana saja. Hai ini dibuktikan dari hasil penelitian ini, yang menunjukkan bahwa jumlah terbanyak pada kelompok yang berpendidikan SMA dibandingkan dengan tingkat pendidikan tinggi. Pendidikan dapat mempengaruhi tingkat pengetahuan seseorang, semakin tinggi tingkat pendidikan seseorang makin mudah menerima informasi, sehingga makin baik pengetahuannya, akan tetapi seseorang yang berpendidikan rendah belum tentu berpengetahuan rendah. Pengetahuan tidak hanya diperoleh dari pendidikan formal akan tetapi juga bias diperoleh melalui pendidikan nonformal, seperti pengalaman pribadi, media, lingkungan dan penyuluhan kesehatan, sehingga bias juga seseorang dengan pendidikan tinggi dapat terpapar dengan penyakit begitu pula sebaliknya (Notoadmojo S. 2010).

\subsubsection{Hubungan Status Pekerjaan Ibu Ter- hadap Pemberian MP-ASI Dini.}

Pekerjaan bukan merupakan halangan bagi ibu untuk memberikan ASI saja atau tidak memberikan MP-ASI terlalu dini untuk bayinya yang masih berumur 0 sampai 6 bulan, ada berbagai cara yang dapat dilakukan seorang ibu agar tetap memberikan ASI saja seperti memerah ASI kemudian di simpan pada lemari es dan dukungan lingkungan kerja sehingga seorang yang bekerja tetap dapat memberikan ASI saja kepada bayi tanpa Makanan tambahan lainnya (Syerlia et al, 2011).

Uji statistik dengan menggunakan program komputer program SPSS dengan uji Chi-square menunjukkan bahwa tidak terdapat hubungan yang bermakna dalam memberikan MP-ASI dini pada bayi umur 6-24 bulan, hal ini di buktikan dengan nilai $\mathrm{p}=0,432>\alpha=0,05$.

Hal ini disebabkan karena adanya faktor yang lebih dominan seperti faktor sosial budaya yang bisa mempengaruhi ibu untuk memberikan MP-ASI dini saja pada bayinya di antaranya ibu 
berfikiran dengan ASI saja maka pertumbuhan anak akan lambat dan tidak merasa kenyang sehingga responden berfikir untuk memberikan makanan tambahan (Syerlia et al, 2011).

Ibu yang hanya bekerja di rumah dan mempunyai banyak waktu di rumah tidak selamanya memberikan MP-ASI tepat pada waktunya, ini terbukti dari hasil penelitian dimana banyak ibu yang bekerja di rumah atau hanya sebagai ibu rumah tangga sudah memberikan makanan tambahan sebelum waktu yang di anjurkan. Banyak ibu yang bekerja di rumah dan bekerja di luar rumah yang mengkombinasikan ASI dengan makanan tambahan seperti bubur instan, walaupun bayi belum layak diberikan MP- ASI (Syerlia et al, 2011).

Menurut peneliti pekerjaan adalah mata pencaharian sehari-hari dari seseorang untuk mencari uang dalam memenuhi kebutuhan seharihari. Pekerjaan berperan besar terhadap seseorang melakukan tindakan pemberian makanan tambahan pendamping ASI (Syerlia et al, 2011). Menurut Lestari (2013), variabel status pekerjaan ibu merupakan faktor yang bersifat memproteksi, artinya ibu yang tidak bekerja akan lebih mendukung dalam pemberian ASI ekslusif dibandingkan ibu yang bekerja. Hal ini dikarenakan ibu yang tidak melakukan pekerjaan di luar rumah (IRT) akan memiliki banyak waktu dan kesempatan untuk menyusui bayinya dibandingkan dengan ibu yang bekerja di luar rumah. Selain itu masih banyak ibu yang beranggapan salah tentang ASI eksklusif, ibu juga merasa khawatir bahwa dengan menyusui akan merubah bentuk payudara menjadi jelek, dan takut badan akan menjadi gemuk. Dengan alasan inilah ibu memberikan makanan pendamping ASI, karena ibu merasa ASI nya tidak mencukupi kebutuhan gizi bayinya sehingga ibu memilih susu formula karena lebih praktis (Lestari, 2013).

Menurut Adisasmito (2008) semakin tinggi tingkat pengetahuan, pendidikan dan keterampilan orang tua terdapat kemungkinan semakin baik tingkat ketahanan pangan keluarga dalam memberikan MPASI. Sebaliknya kurangnya pengetahuan, pendidikan dan keterampilan orang tua kemungkinan tidak mampu menyediakan bahan makanan yang baik berupa MPASI bagi anak sehingga beresiko tinggi menderita kurang gizi.

Pengetahuan ibu tentang MPASI umumnya masih kurang yaitu $62,5 \%$. Jika dilihat dari golongan umur anak, pengetahuan ibu yang kurang hampir sama pada ketiga golongan umur yaitu 21,9\%. Hal ini hampir sama dengan penelitian sebelumnya tentang MP ASI di Desa Bowong Cindea Kecamatan Bungoro Kabupaten Pangkep menunjukkan bahwa tingkat pengetahuan ibu tentang Makanan Pendamping ASI (MP - ASI) berada pada tingkat kategori kurang dengan jumlah 30 orang $(60.0 \%)$. Hal ini disebabkan karena masih banyak ibu-ibu di lokasi penelitian yang tingkat pendidikannya Tamat SD dan tidak bekerja (Adisasmito, 2008).

\section{SIMPULAN}

\subsection{Simpulan}

1. Ada hubungan antara pendidikan ibu dengan pemberian MP-ASI dini pada Balita usia 624 bulan.

2. Tidak ada hubungan antara pekerjaan ibu dengan pemberian MP-ASI dini pada Balita usia 6-24 bulan.

\subsection{Saran}

Diharapkan pada peneliti lain untuk melanjutkan penelitian yang serupa dengan faktor lainnya seperti dukungan keluarga sikap ibu dan jarak rumah responden dengan sarana kesehatan.

\section{REFERENSI}

Adisasmito W. 2008. Sistem Kesehatan. Jakarta: Raja Grafindo Persada

Aritonang. 2006. Busung Lapar. Jakarta: Media Pressindo.

Asmarudin Pakhri, Fahrizal R. Pangestu, Salmiah. 2015. Pendidikan Orang Tua, Pengetahuan Ibu, Pemberian Makanan Pendamping Asi Dan Status Gizi Pada Anak Usia 6.24 Bulan Di Kelurahan Taroada Kabupaten Maros. Media Gizi Pangan. Volume XIX Edisi 1.

Depertemen Kesehatan Rebuplik Indonesia. 2010. The World Health Report 2009. http://www.litbang.depkes.go.id.// 
Gibson, RS,. Ferguson, EL., \& Lehrfeld, J. 2008. Complementary Foods For Infant Feeding In Developing Countries: Their Nutrient Adequacy And Improvement. European Journal of Clinical Nutrition. 72.p. 421429.

Kementerian Kesehatan Republik Indonesia. 2011. Profil Kesehatan Indonesia 2010. Jakarta: Kementerian Kesehatan Republik Indonesia.

Kemenkes. 2014. Riset Kesehatan Dasar 2013. Jakarta.

Lestari, Ika. 2013. Pengembangan Bahan Ajar Berbasis Kompetensi. Padang: Akademika Permata.

Notoadmojo S. 2010. Promosi Kesehatan dan Ilmu Prilaku. Jakarta: Rineka Cipta.

Notatmojo S. 2011. Kesehatan Masyarakat Ilmu dan Seni. Jakarta: Rikena Cipta.
Prabantini, Dwi. 2010. A to Z Makanan Pendamping ASI. Yogyakarta: Andi Offset.

Santoso, S dan Anne Lies Ranti. 2004. Kesehatan dan Gizi. Jakarta: Penerbit Rineka Cipta.

Syerlia Darman, Lydia Fanny, Hj. Fatmawaty Suaib, Nadimin. 2014. Hubungan Pendidikan, Pengetahuan Dan Pekerjaan Ibu Dengan Pemberian Mp-Asi Dini Di Desa Bonto Marannu. Media Gizi Pangan. Volume XVIII Edisi 2.

UKK Nutrisi dan Penyakit Metabolik IDAI. 2015.Rekomendasi Praktik Pemberian Makan Berbasis Bukti pada Bayi dan Batita di Indonesia untuk Mencegah Malnutrisi. Rekomendasi IDAI. 